\title{
A CASE OF TRIPLE POST OPERATIVE CYST
}

\author{
By
}

\author{
Y. TORIYAMA M.D., M. OKA M.D, H. YOSHIHAMA M.D. \\ AND F. YONEZAWA M D.
}

\section{From the Musashino Red Cross Hospital Department of Otorhtnolaryngology}

Triple post operatıve cyst in a 62 years old man was reported. Left pansinectomy was done 25 -years ago, and again he was operated for left post operative maxillar cyst 20 yearslater.

Recently we found post operative cyst in left frontal sinus and ethmoidal cells.

Only two cases of double post operative cyst have been reported in Japan, and these two cases were that of othmoidal cells and maxillar sinuses.

This case of triple post operative cyst might be said to be the first reported case in Japan.

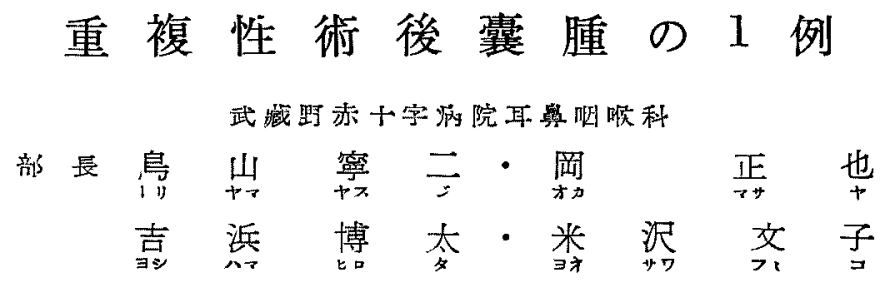

‘術後垔腫の增告は多数あり，今更言を要さぬ程てある

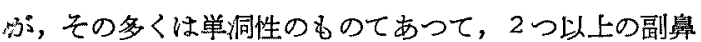
腔から同時に発生したといらるのは非常に少い。

我ふはその1症例を経験したのてこっにその大要を報 告する.

症例

62 才男子. 主訴左内觜部の㯵脤

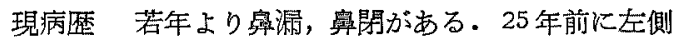
副與腔炎根治手術を口腔法，奥外法により某病院てう 讨，その後の経過は良好てあつた５年前に左煩部腫脹

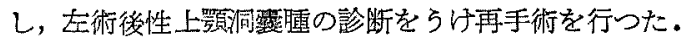
その後異常をみなかつたが，約 1 年前より左内㫮部の蕾 脹あり，消褪せぬので当䄬を和とずれた。

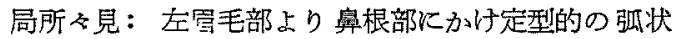
の手術洀痕があり，般痕に異常はない. 左滑革窝は趁隆 し，その部を被う上皮に翂化はないが，弹力性表面山凹 不定，不規則な腫瘤がある・圧痛なく，波動を認める。

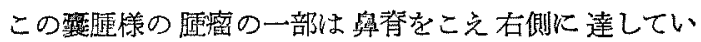
る.

左眼裂は右に比して㹧く，明らかに下方に下り，眼球

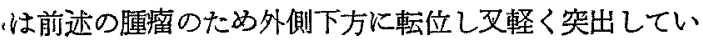
る. 左眼球結償は中等度充血をみる. 左眼球運動は内側
視がや〉障碍されているようてあるがまず正常てある。 左鼻内所見ては異常分㕳を認めず，中・下甲介正常 であり，中與道も開いている. 右鼻内所見は，中甲介浮 腫性に䐍脹し，中鼻道の粘朕も同様に脜脹しているが分 泌物はない，後鼾鏡検查て特に異常はない。

内皆部の画溜を穿刺すると，黄褐色粘程な分汹液が出 たが，登沫，培盖て細菌は証明できなかつた・

レントゲン所見 左前頭洞は著しく抬大し中等度の 陰影があるが,下1/2位ては院影はや〉うすくはつてい る. 左腿架上縁に骨欠損像がある. 右前頭洞は境界不焦 明てあり，一様の漹い㓌影て被われ，一見右前頭洞旡影 をかくかとも思わせる．左右箒骨蜂察は殊にその前部は 一椂に蟹明な像を呈しているが，蜂窗隔壁つ明膫な陰影 に乏しい，右上顠洞は境界解明，明るい陰影あり，左上 顎恫は明䁖な境界を示さず，骨硬化像が強い。

手術所見 前回行なわれた 手術痉痕に沿つて皮切を

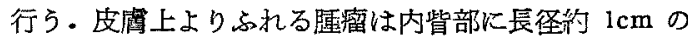
哪形を呈し，その上部に誐痕がみられた。眼窩壁を上外 万に㔀離すると，眼虽上縁の罴根部に近く，骨縁より䄪 $5 \mathrm{~mm}$ 下に $3 \times 2 \mathrm{~mm}$ 大の骨久損があり，この部より前 頭洞部の粘膜が露出していた・前述の卯形の高腫縁にそ い骨整除をすると，この襄腫は眼㮤内壁に沿い樑く後部 


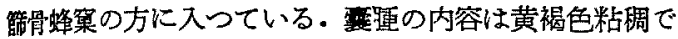

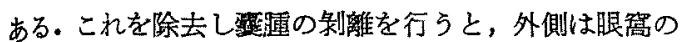
内側，下壁て眼窠壁をかき，眼菒骨膜と粗に痖着し，最 梁部は後部簑骨䗋棎に達していた，下方は，同部よりほ \水平に前部，中部節骨䗋雀底に近く及ひ，固有奥腔之 は所により一層の粘膜あるいは一連の蜂案て界されてい

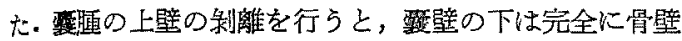
の形成が双られ，左番前頭管は存在せず，又前迹した眼 架上縁の骨欠損部上りみられた左前頭洞部の粘膜腔への

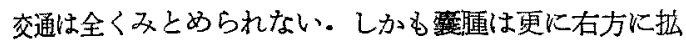
大して㧍り，壁にそい别離を行うと，右側前頭同底の骨 壁にそい右眼毣内縁に迄達していた。文，右前頭洞底に

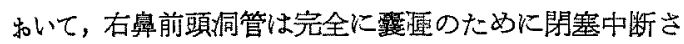
れているが，前頭洞底に僅かに 展孔として残在してを クこつから乾酷様物質の充泟している右前頭洞がうか

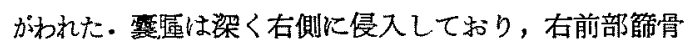
蜂策を破墁し，この部を占居していた・右側に侵入した 要通の下方は一層の粘膜て固有鼻腔と界されていた・か くて左右籍骨蜂巢に存在した要堙の摘出を終り，次いて 全く鄵絶せれている左前頭洞部の褧連に手をつけた。眼

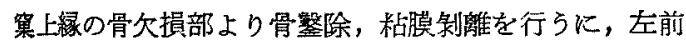

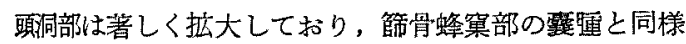
な黄褐色秥调な内容をいれている・この前頭洞部の翼腫 も楽任新離がてき，又，右前頭洞との交通，中隔の欠 損，硬脸膜の露出等はなかつたか，前述したように，鼻 前頭洞管の開口は全くなく，完全に独立した露通を形成 していた。次いて術創の平滑化と共左番内上り広く笠

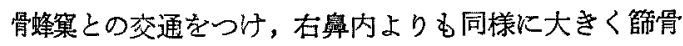
蜂笨を開き，更に右前頭洞底をできるだけ広く錐除し前 頭洞内の洗紧を行い乾酪样物質を除去し，左右の前頭 洞・笠骨蜂简を一大腔間につなげ，術創を閉鎖して術を 終了 (四参昭).

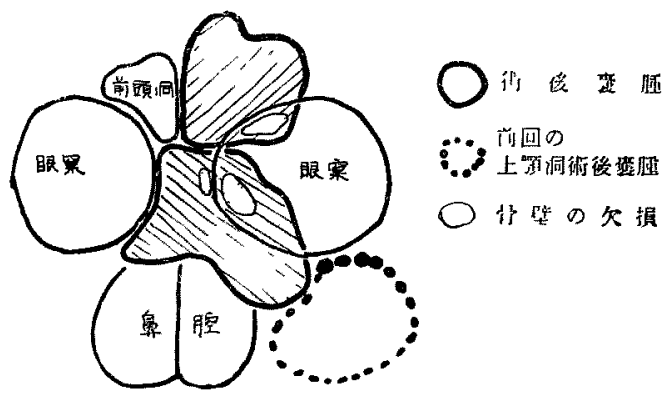

経過術後の経過良好てあり第 15 病日に退院, 以後 外来治寮を行つた。
考按

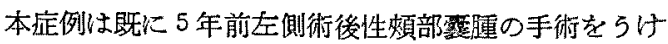
て括り，当時の手術所見乞の他よりしてこのものが術後 性酤侢てあつたことは明らかてある。しかも今回既迹し たごとく，左節骨蜂集ムニフェレの如き外観を呈し，手

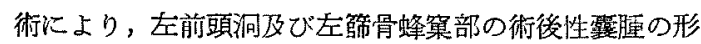
成をみている。つ立り，左側に括ける前頭洞，節骨蜂

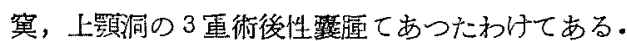

術後性琵腄についての報告は実に多数てあり，その多 梾性についても多くの記述かなされているしかし重複 例についての報告はまことに少なく，藤田，内海・福 良の二症例しかえられずしかもこの 2 症例る，上颚洞の

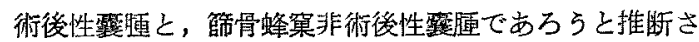
れている. 又, 維田, 山口は絪外法に上る前頭洞手術後. に発生した篩骨䗋巢ムコフェレと，残存していた前頭洞 の各 1 例を報告されているが，これは前回の前頭洞手術。 時に，前頭恫に手をつけた如き変化かみられなかつたと 記載してあり，この2 症例を重複術後性罢腫とすべきか心 否かは断定しかたいが，これらを入れても4症例しかみ られず本例は第 5 番目のものてあり，しかも3 箽複例と しては始めてのものてある.

\begin{tabular}{|c|c|c|}
\hline 藤 & 田 & 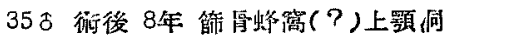 \\
\hline 內。 & 要是 & 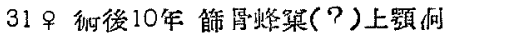 \\
\hline 隻 & 田 & 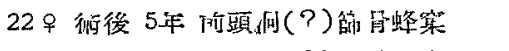 \\
\hline 山 & 口 & 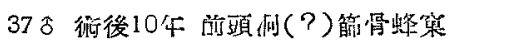 \\
\hline 本 & 例 & 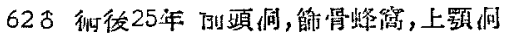 \\
\hline
\end{tabular}

その1例1例についてみれば，諸事項は文献にみる術

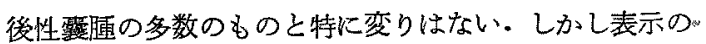

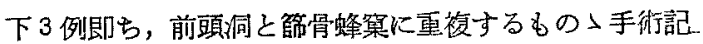
载をみると，前頭洞部の術後裂婳はすべて笠骨蜂菒部の

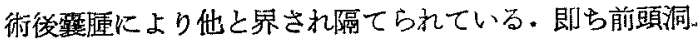

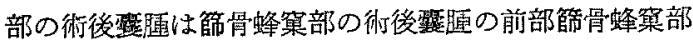

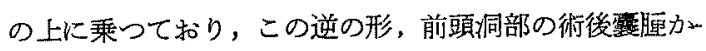

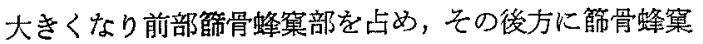

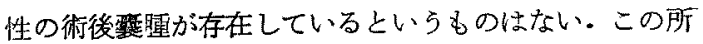

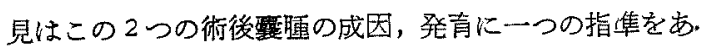
たえよう・

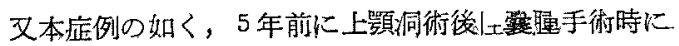
は前頭涧，篩骨蜂窠部のそれは湿著てなく放置されてい るのてあるから，今後も術後性露垍例においては前回加 えられた手術方法により各部位における電複性を考慮す 
る必要がると考えられる。

又前頭洞部の術後性嚅腫についてみれば，現在迄の報 告例のすべてが鼻外法によつた 手術の後に 発生してお り，鼻内法によるものでの発生が報告されていない点に 興味をひかれる。

\section{結語}

62 才男子にみられた 3 重複術後性霬腫について 報告 した。

25 年前に左側沉副鼻腔炎根治手術をらけ，5年前に左 上顎洞術後性垔腫の手術をらけ，更に今回左前洞，節骨 蜂窩に重複した術後性囊腫の発生をみたものである。

又同時に右前頭洞の乾酪性炎も併発していた。重複性 術後覇婳の文献上の報告についてのべた。
文献

1）稚田：名古屋医学会雑誌，44,149；1936. 2) 藤 田：耳悬咽喉科，9，219；1936。3）阿海，福盲：東 京医票新誌，3048，2366；1937 4）山口：日耳畀, 48,826 ; 1940.

本論文の裂旨は炤和 34 年 1 月の 関東地方会 にてのペた。

擱筆するに゙あたり種々御指䓕御教示して下さ つた堆田胤次部長に厚く感謝致します。

（原稿到咭 $=$ 昭利 34.8 .31 日）

\section{ブロス新型耳鼻科ユニット}

58 型（騷晋防止亚に振動防止藵置付） 耳囬咽喉科の診察治療用として最も新しい完備された实用的 な裝置であります。全体は全鋼鉄製で移動車が取り付けてあ

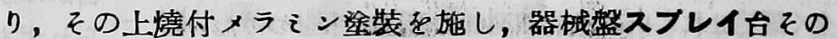
他の部分にはステンレス磨板，デザインが優美で診察室に最 るふさわしいすのであります。

キヤビネットには最新式の騷晋防止亚に防振装㽡を取り付け 治療上困難とされた騷畐を取除かれた。

ユニシトの部品並に附属品

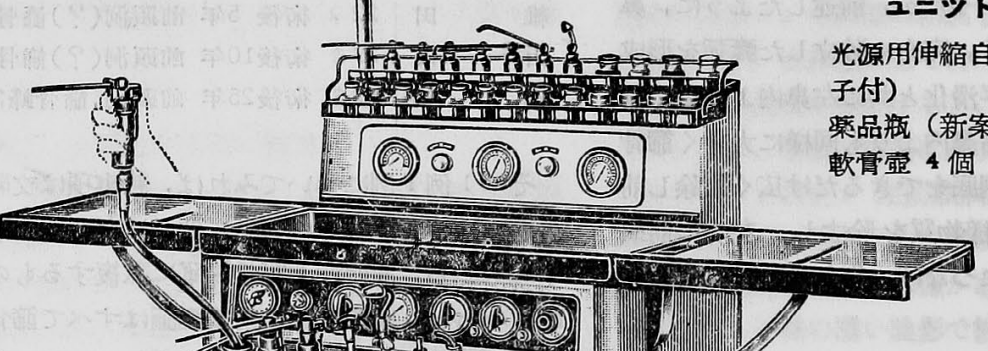
光源用伸縮自在奄㓅（笠前部は防熱硝 子付）

臬品瓶（新案開閉蓋付） 13 個

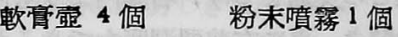
瓶型ネブ タイザー1 個

フトミザー5 個 コンプレンサ直結へン ドル付スプレイー3個

詳しいパン レットは申⿺辶 次第野送致し ます) (新案特許)

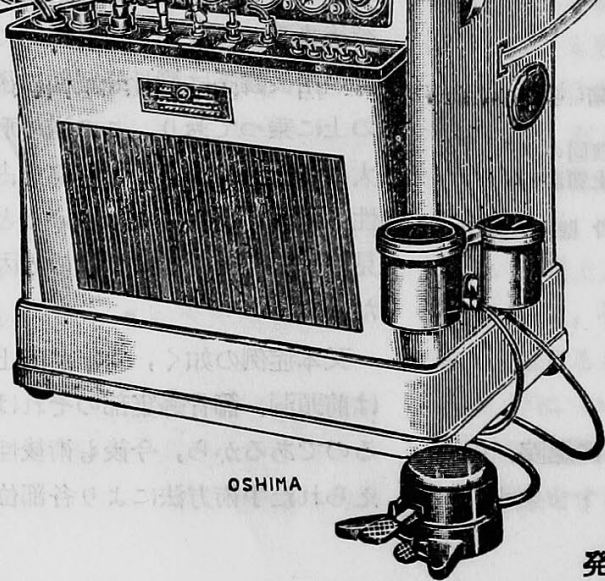

発売製造元 禁社大島医科器械店 